\title{
Fecundity and development of the bentho-pelagic copepod Pseudocyclops umbraticus: effects of temperature
}

\author{
Cinzia Brugnano, Antonia Granata, Letterio Guglielmo, Roberta Minutoli, \\ Giacomo Zagami*
}

Department of Biological and Environmental Sciences, Messina University, Viale Ferdinando Stagno d'Alcontres 31, S. Agata, 98166 Messina, Italy

\begin{abstract}
The shallow-living, bentho-pelagic copepod species Pseudocyclops umbraticus was collected seasonally during nighttime in the brackish waters of Lake Faro (north-eastern Sicily). It showed marked seasonal fluctuations in population abundance, with maximum numbers occurring in summer. In the laboratory, mean daily egg production rates (EPR) of $P$. umbraticus were positively correlated with temperature, with values ranging from (mean $\pm \mathrm{SD}$ ) $2.3 \pm 6.3$ eggs female $\mathrm{e}^{-1} \mathrm{~d}^{-1}$ at $14^{\circ} \mathrm{C}$ to $6.1 \pm 10.2$ eggs female ${ }^{-1} \mathrm{~d}^{-1}$ at $24^{\circ} \mathrm{C}$. In terms of total egg production over the entire female lifespan, maximum values occurred at $14^{\circ} \mathrm{C}$ and minimum at $24^{\circ} \mathrm{C}$. At 12 and $32^{\circ} \mathrm{C}$, females were able to survive, but they stopped egg production. Temperature also dramatically affected female copepod lifespan, which was shorter at higher temperatures. Development time for the eggs decreased with increasing temperature, as did development time from egg to adulthood. Recruitment rate was low at lower temperatures. The distinctive egg-laying behaviour of $P$. umbraticus is described here for the first time. The EPR in P. umbraticus is relatively low compared to other pelagic copepods, but within the ranges reported for egg-carrying species. Greater fecundity at higher temperatures compared to other subtemperate species indicates that $P$. umbraticus is well adapted to the higher temperatures of coastal brackish basins, where it contributes to the biodiversity of the plankton community at night as it migrates from the substratum into the water column.
\end{abstract}

KEY WORDS: Temperature - Egg production rate Parental care Pseudocyclops umbraticus · Hyperbenthic habitat

Resale or republication not permitted without written consent of the publisher

\section{INTRODUCTION}

Calanoid copepods are one of the most important constituents of marine pelagic ecosystems, as they are grazers on phytoplankton and prey for animals at higher trophic levels (e.g. fish, Mauchline 1998). The bentho-pelagic copepods are a rare but interesting component of the calanoids, comprising the most basal species known in this order (Huys \& Boxshall 1991). In addition, the bentho-pelagic calanoids have been referred to in many studies as demersal, bentho-planktonic and hyperbenthic because of their habitat, which is at and around the sediment-water interface.

Bentho-pelagic calanoids are only present in the zooplankton community at night (Zagami \& Brugnano 2013), which confirms the hypothesis of their circadian vertical migration between the bottom and the water column (Damkaer 1970, Alldredge \& King 1985, Ohtsuka 1985, Jacoby \& Greenwood 1988, Campolmi et al. 2002). Measurements of the lifehistory parameters of these copepods, such as development and egg production, will therefore provide useful information about energy transformation in 
pelagic food webs during the night. Bentho-pelagic coupling of calanoids occurs mostly in autumn, resulting in increased abundance and, in some Mediterranean coastal brackish water environments such as Stagnone of Marsala and Lake Faro (Italy), a marked contribution to functional diversity (Campolmi et al. 2002, Zagami \& Brugnano 2013).

The life-history parameters of rare bentho-pelagic copepods can be difficult to determine from field population data, because of the inadequacy of traditional zooplankton sampling methods in capturing them in their daytime habitat. Therefore, laboratory rearing is often the method used for these analyses. Life-history traits have only been studied in the field for Pseudocyclops xiphophorus (Brugnano et al. 2009), which was first recorded in the Mediterranean Sea in Lake Faro (Zagami et al. 2005), as its daytime habitat in the fouling material made it easily available with manual sampling methods.

To date, many experimental studies have shown that water temperature and food conditions are the most important factors affecting the life-history parameters of copepods (see Ban 1994, and references therein). However, egg production and development times can differ between closely related genera, within a genus, and even within the same species (Corkett \& McLaren 1978). This is unexpected, because of the general relationship that exists between temperature and metabolic activity.

Pseudocyclops umbraticus is a bentho-pelagic calanoid (size range 0.6 to $0.7 \mathrm{~mm}$ ) that lives on the nearshore bottom-water substrate interface of Lake Faro. Its spatial distribution is determined mainly by the substratum rather than by any physical para- meters (Zagami \& Brugnano 2013). Temperature is the only important environmental factor that affects the seasonal abundance pattern of $P$. umbraticus, although potentially in an indirect manner, as higher temperatures induce lower oxygen concentrations at the lake bottom, therefore restricting the available habitat (Zagami \& Brugnano 2013).

In the present study, egg production rates (EPR), development and egg-laying behaviours of $P$. umbraticus were studied in the laboratory at different temperatures under food-satiated conditions. The findings were then considered in relation to the natural seasonal fluctuations that occur in the population abundances of $P$. umbraticus in Lake Faro, and also in relation to what is known of the temperature effects and reproductive patterns of the congener species $P$. xiphophorus, which is present in the same environment although it lives on a different substrate (biological material on ropes suspended in the oxygenated layer, and mooring posts all around the lake).

\section{MATERIALS AND METHODS}

\section{Study area}

Lake Faro is a coastal basin located in the northeastern tip of Sicily (surface area $263600 \mathrm{~m}^{2}$, max. depth $29 \mathrm{~m}$ ) (Fig. 1). It has the typical features of a meromictic basin; i.e. an oxic epilimnion (surface to 10-12 $\mathrm{m}$ in depth) and an anoxic hypolimnion (15 m to the lake bottom). It is characterised by large fluctuations in its physico-chemical parameters, especially temperature $\left(10\right.$ to $28^{\circ} \mathrm{C}$ ), salinity (34 to 37 ) and dis-

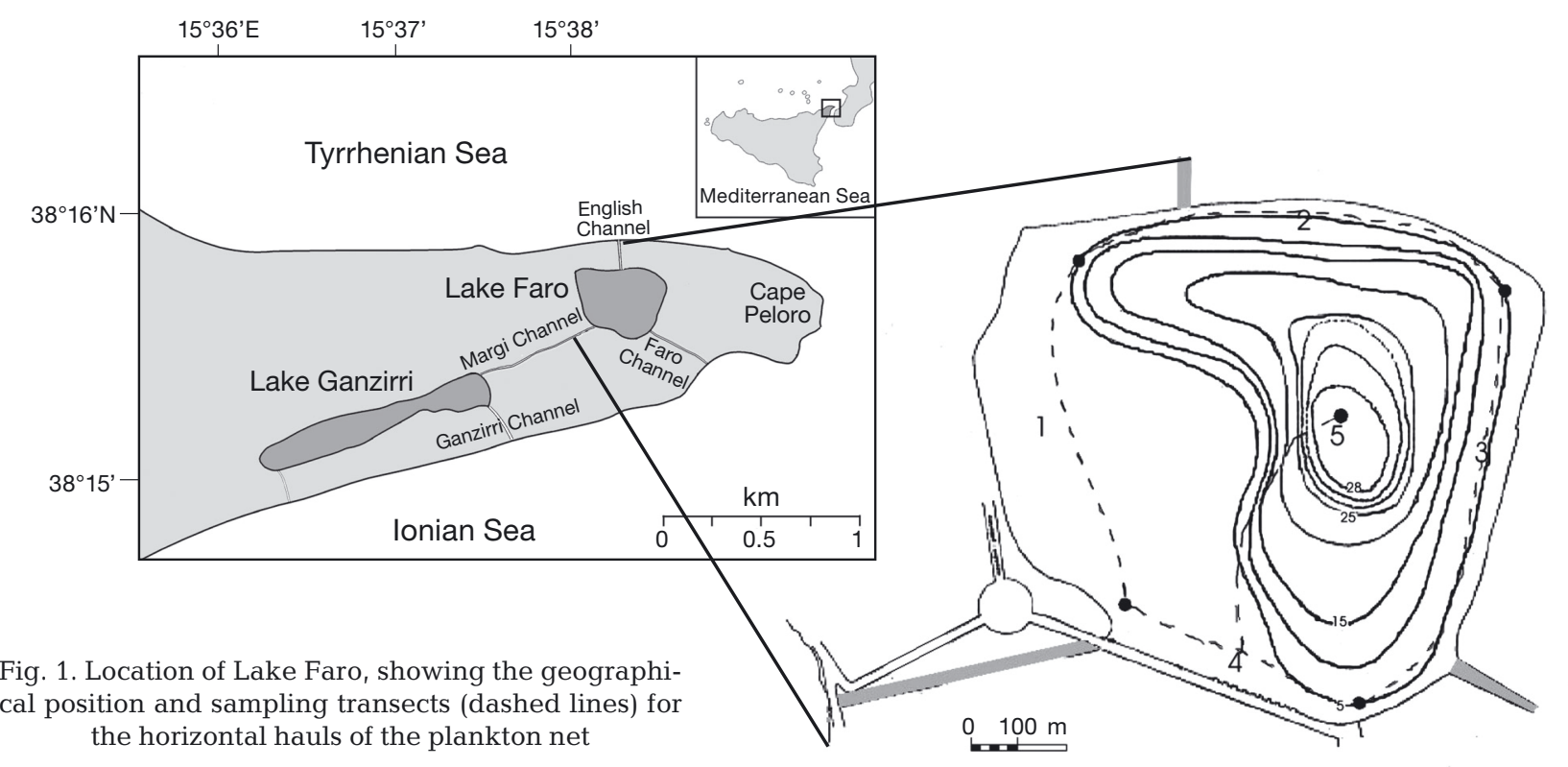


solved oxygen (absent near the lake bottom in the central area; $8.3 \mathrm{mg} \mathrm{l}^{-1}$ at the surface along the shore). These layers are separated by a metalimnion, within which strong blooms of anoxygenic phototrophic bacteria result in the periodic development of a red water layer (Genovese 1963, Trüpper \& Genovese 1968). This physical and chemical stratification is particularly sharp in summer, when the anoxia can typically extend up to the lower mixolimnion, and conspicuous blooms of photosynthetic sulphur bacteria develop. The main component of these blooms has been identified as Chlorobium phaeovibrioides (Sorokin \& Donato 1975), which is a well-characterised member of the Chlorobiaceae that is highly adapted to low light intensities. Lake Faro is connected via a shallow channel to the Straits of Messina, which separate the island of Sicily from the Italian peninsula. Another channel that is silted up for most of the year is artificially opened for a few days during the hottest summer period (June through August), thus establishing communication with the Tyrrhenian Sea to allow better water circulation into the lake.

On the 3 sides of Lake Faro that correspond to Transects 1, 2 and 4 (Fig. 1), there are great masses of the chlorophyte alga Chaetomorpha linum (O. F. Müller) Kützing, and the bottom is muddy and rich in organic detritus. Along Transect 3 of Fig. 1, the lake bottom consists of pebbles and gravel and is covered by Cymodocea nodosa (Ucria) Ascherson and Ulva laetevirens Areschoug. In the central area of the lake and associated with the anoxic lake-bottom waters, the 'fouling' material is the only substrate type in the oxygenated stratum. This material is comprised of benthic organisms, such as ascidiaceans (Styela plicata, Ciona intestinalis, and other unidentified species), polychaetes and bryozoans that are attached to submerged ropes, in which a harpacticoid, cyclopoid and hyperbenthic calanoid copepod community lives.

\section{Sampling methods and laboratory experiments}

In May, June and November 2004, and in January and April 2005, zooplankton samples were collected from Lake Faro during the day and at night along 5 transects (Fig. 1): 4 along the sides of the lake, and the fifth into the centre of the lake. All of the samples were collected using a rectangular mouth plankton net (mouth area $0.18 \mathrm{~m}^{2}$, mesh size $200 \mu \mathrm{m}$ ) equipped with a flowmeter (Hydrobios). Along the shallow shorelines of the lake (max. depth 1 to $2 \mathrm{~m}$ ), the net was towed at a few $\mathrm{mm}$ from the lake bottom, while in the central area of the lake, it was towed horizon- tally 2 to $3 \mathrm{~m}$ below the water surface. Contemporaneous to each sampling, temperature, salinity and dissolved oxygen were measured using a multiparameter probe (YSI 6920, for temperature, conductivity and dissolved oxygen).

Zooplankton samples were placed into plastic containers and immediately brought to the laboratory where the $P$. umbraticus specimens were sorted out and counted under a stereo microscope and then transferred to a sample flask with $100 \mathrm{ml}$ sterile sea water (salinity $=37$ ). The sample flask was placed in a thermostatic cell at $18^{\circ} \mathrm{C}$.

Female-plus-male pairs were taken from the aquarium when they reached the CIV-CV stage and placed as isolated pairs in crystallisation dishes. These dishes were monitored frequently (every $\sim 6 \mathrm{~h}$ ) for moults to record the initial fertilisation and spawning of the females. Groups of 5 replicate pairs were incubated at each of the following temperatures: $12,14,18,24$ and $32^{\circ} \mathrm{C}$. Each pair was monitored daily during its entire lifespan, to record EPR in relation to temperature, and to observe egg-laying behaviour. The eggs, nauplii and copepodites from each parental pair were monitored until adulthood. EPRs were calculated as the mean number of eggs produced per female per day, including all of the incubated females. Recruitment rates were calculated by estimating the percentage ratio between the copepods that survived to adulthood and the nauplii that hatched from the eggs.

In the aquarium and in the pair dishes, specimens of $P$. umbraticus were reared on a mixed diet given in excess $\left(>10^{3}\right)$ of the incipient limiting concentration for small-size copepods such as Pseudocyclops spp. (e.g. Corkett \& McLaren 1978, Kiørboe et al. 1985, Runge 1988). The diet consisted of 3 phytoplankton species: Tetraselmis suecica, Pavlova lutheri and Isochrysis galbana. All 3 of these phytoplankton species were grown in Walne medium at $18^{\circ} \mathrm{C}$ under a 12:12 h light:dark cycle; $\sim 7 \mathrm{~d}$ old cultures were used.

\section{Statistical analysis}

Kendall's tau correlation analysis was run to evaluate the relationships between the abundance data and the environmental parameters measured in the present study. This analysis is a non-parametric measure of rank association that is based on the number of concordances and discordances in paired observations.

One-way ANOVA was run to test for significant differences in daily egg production across the exper- 
imental temperatures; Tukey's pairwise comparisons were used to evaluate the most significant differences in egg production between the temperatures. These tests were performed using the PAST software package (Hammer et al. 2001). To test for differences in the species-specific responses to temperature between $P$. umbraticus and the congeneric species $P$. xiphophorus, linear interpolation was used to calculate the missing values at all corresponding temperatures in both species. Linear regression analysis was used to predict the development time of the eggs, and from eggs to adulthood, at the limiting temperatures of 12 and $32^{\circ} \mathrm{C}$. These 2 analyses were performed by computing the relative formulae using an Excel 2010 spreadsheet of the Microsoft Office package. The following formula was used for the linear interpolation, solved for $y$ (temperature):

$$
y=y_{1}+\left(x-x_{1}\right) \frac{y_{2}-y_{1}}{x_{2}-x_{1}}
$$

where $x$ is time, in hours for development time of eggs and in days for development from egg to adulthood.

\section{RESULTS}

\section{Seasonal and spatial patterns of abundance and environmental parameters}

The temperature of Lake Faro varied between a maximum of $25.6^{\circ} \mathrm{C}$ in June along Transect 2, to a minimum of $11.8^{\circ} \mathrm{C}$ in January along Transect 4 (Fig. 2). The salinity reached its peak (36.1) in November along Transect 1, with the lowest salinity (31.5) measured in May along Transect 2 (Fig. 2). Dissolved oxygen concentrations oscillated between $6.4 \mathrm{mg} \mathrm{l}^{-1}$ in May along Transect 1 and $4.2 \mathrm{mg} \mathrm{l}^{-1}$ in November along Transect 2 (Fig. 2).

Pseudocyclops umbraticus occurred in Lake Faro throughout the year, with increasing abundance from May 2004 onwards, at which time the population was almost completely comprised of adults. The population attained a maximum abundance of 2.83 ind. $\mathrm{m}^{-3}$ (as adults and copepodites combined) in June 2004 along Transect 2 (Fig. 3). Another peak in abundance of 1.22 ind $\mathrm{m}^{-3}$ (adults plus copepodites) was recorded in November 2004 along Transect 1. Considerable numbers were also recorded in January 2005 along Transect 4, with decreased abundances by April 2005. The seasonal abundance patterns did not show any significant relationships with any environmental parameter with the exception of salinity, which had a significant negative effect on the population abundance (Kendall's tau $=-0.33, \mathrm{p}=0.02$ ).
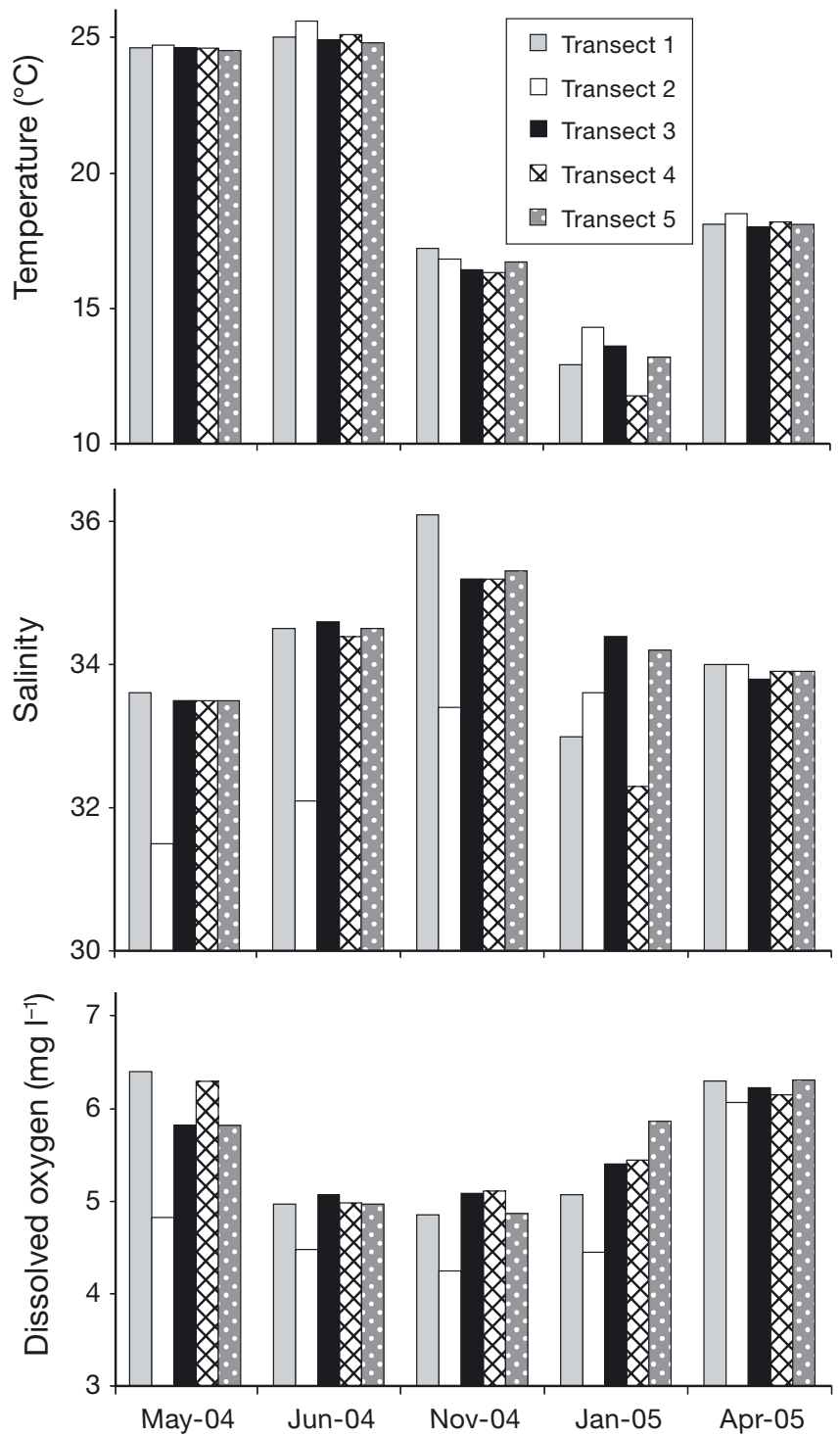

Fig. 2. Environmental parameters of salinity, temperature and dissolved oxygen along the 5 sampling transects during the sampling months

\section{Fecundity experiments in the laboratory}

The mean daily EPR throughout the full spawning lifetime of females was (mean $\pm \mathrm{SD}$ ) $2.3 \pm 2.9$ eggs female ${ }^{-1} \mathrm{~d}^{-1}$ at $14^{\circ} \mathrm{C}, 4.9 \pm 5.2$ at $18^{\circ} \mathrm{C}$, and $6.1 \pm 10.2$ at $24^{\circ} \mathrm{C}$. At 12 and $32^{\circ} \mathrm{C}, P$. umbraticus females survived but did not reproduce. The mean daily EPR showed marked oscillations throughout the spawning period (Fig. 4). Across the tested temperatures, spawning rates were characterised by 3 phases (although these were less clear at $14^{\circ} \mathrm{C}$ ): a first phase with low initial daily EPR, a second phase in which fecundity reached the maximum levels characterised by each temperature, and a last phase characterised 


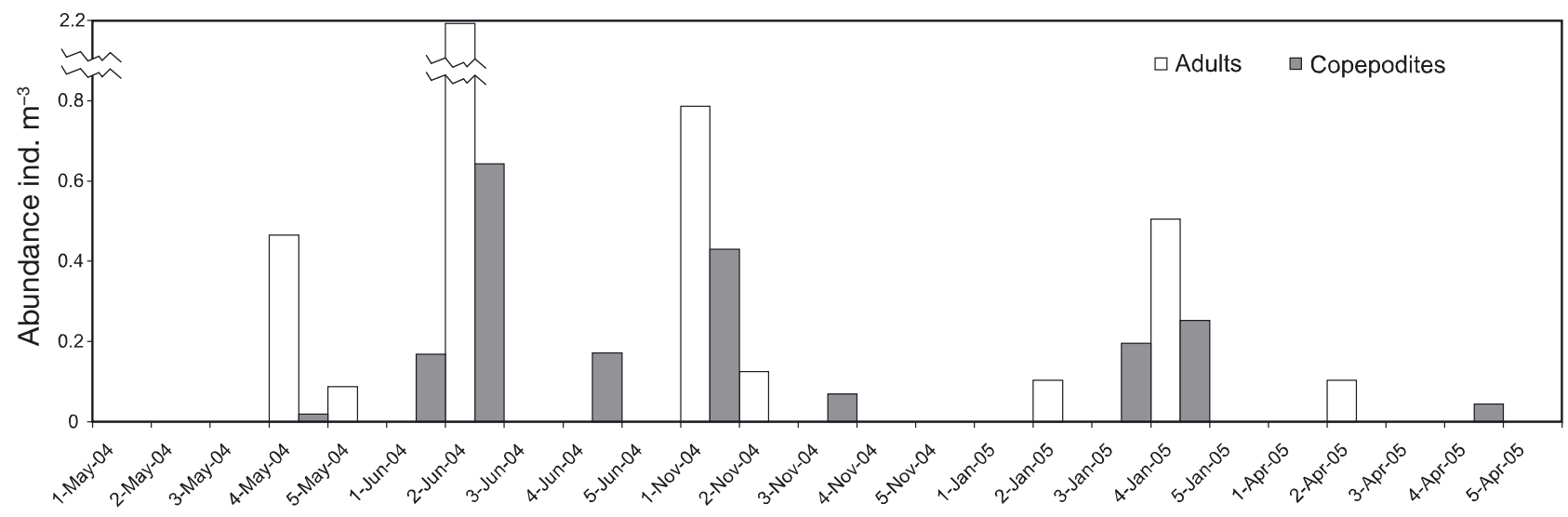

Transect-Month-Year

Fig. 3. Pseudocyclops umbraticus adult and copepodid abundances (as indicated) along the 5 sampling transects during the sampling months
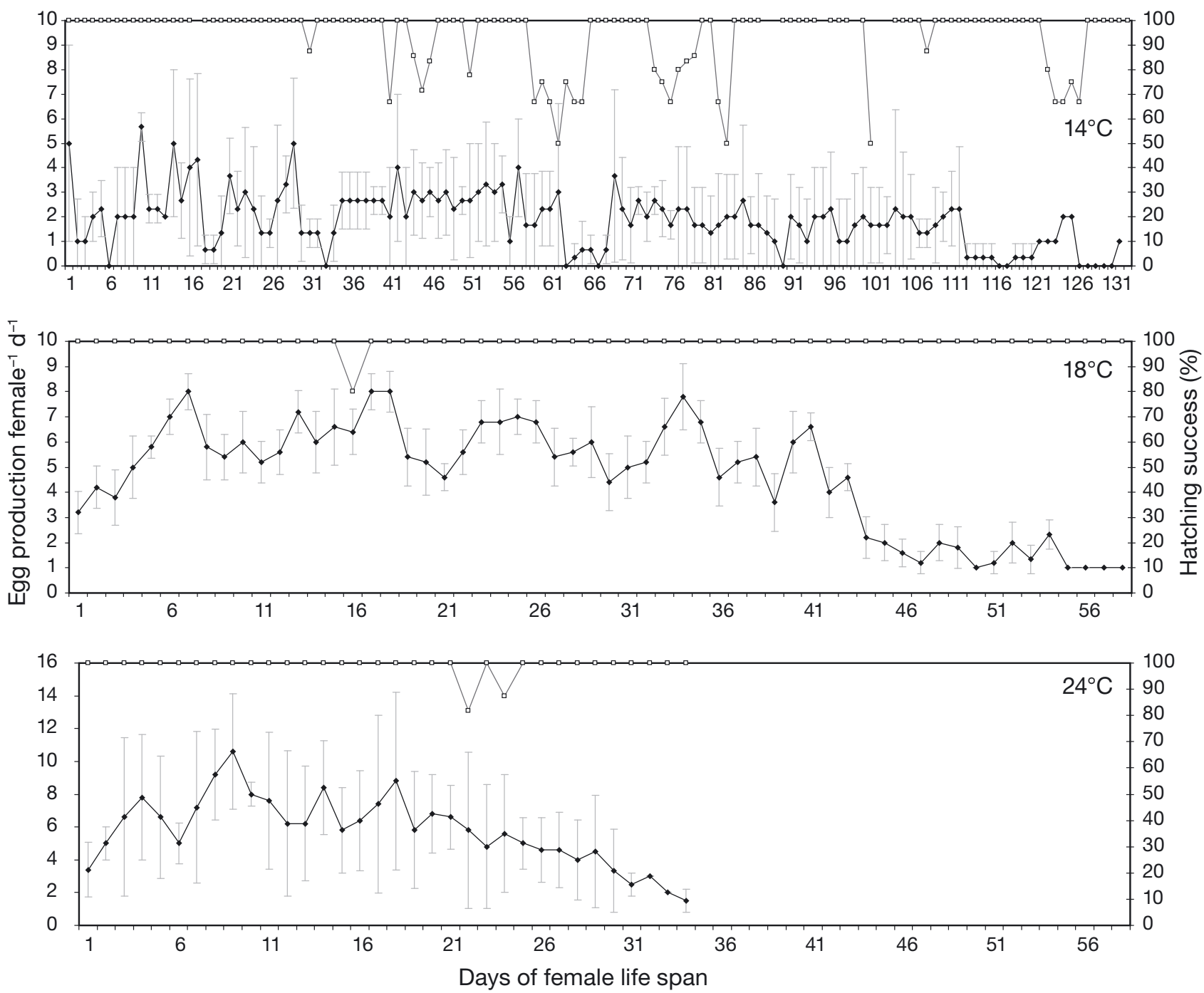

Fig. 4. Pseudocyclops umbraticus mean daily egg production rates ( $\bullet$ ) and hatching success ( (口) at 14,18 , and $24^{\circ} \mathrm{C}$. Note change of $y$-axis scale for $24^{\circ} \mathrm{C}$ (due to the higher production), and change of $x$-axis scale for $14^{\circ} \mathrm{C}$ (due to the longer spawning period) 
Table 1. One-way ANOVA performed on the mean daily egg production of Pseudocyclops umbraticus to test for differences in fecundity responses among temperatures. Significant values are highlighted in bold. Levene's test for homogeneity of variance based on means: $p$ (same) $=0.0138$; based on medians: $\mathrm{p}($ same $)=0.01572$. Welch $F$-test in the case of unequal variances: $F=67.1 ; \mathrm{df}=63.31 ; \mathrm{p}=2.288 \times 10^{-16}$

\begin{tabular}{|lccccc|}
\hline & $\begin{array}{c}\text { Sum of } \\
\text { squares }\end{array}$ & df & $\begin{array}{c}\text { Mean } \\
\text { square }\end{array}$ & $F$ & p(same) \\
\hline Between temperatures & 284.337 & 2 & 142.168 & 53.66 & $\mathbf{1 . 6 4 \times \mathbf { 1 0 } ^ { - \mathbf { 1 6 } }}$ \\
Within spawning days & 262.315 & 99 & 2.64965 & & \\
Total & 546.652 & 101 & & & \\
\hline
\end{tabular}

Table 2. Tukey's pairwise comparisons of the differences in Pseudocyclops umbraticus mean daily egg production among temperatures. Significant values are highlighted in bold

\begin{tabular}{|c|c|c|c|}
\hline$Q \quad \mathrm{p}$ (same) & $14^{\circ} \mathrm{C}$ & $18^{\circ} \mathrm{C}$ & $24^{\circ} \mathrm{C}$ \\
\hline $14^{\circ} \mathrm{C}$ & & $1.00 \times 10^{-4}$ & $1.05 \times 10^{-4}$ \\
\hline $18^{\circ} \mathrm{C}$ & 12.93 & & 0.933 \\
\hline $24^{\circ} \mathrm{C}$ & 12.43 & 0.5022 & \\
\hline
\end{tabular}

by a slow decline in daily egg production (Fig. 4). One-way ANOVA demonstrated significant differences in mean daily EPR among the temperatures tested (Table 1). Tukey's pairwise comparisons estimated more significant differences in the daily mean EPR between the 14 and $18^{\circ} \mathrm{C}$ pairs and the 14 and $24^{\circ} \mathrm{C}$ pairs, than between the 18 and $24^{\circ} \mathrm{C}$ pairs (Table 2).

Hatching success was very high on average, and ranged from about $100 \%$ at $20^{\circ} \mathrm{C}$ to $94.8 \%$ at $14^{\circ} \mathrm{C}$. Hatching success was lower at $14^{\circ} \mathrm{C}$, although it never dropped below $50 \%$ (Fig. 4). The maximum mean

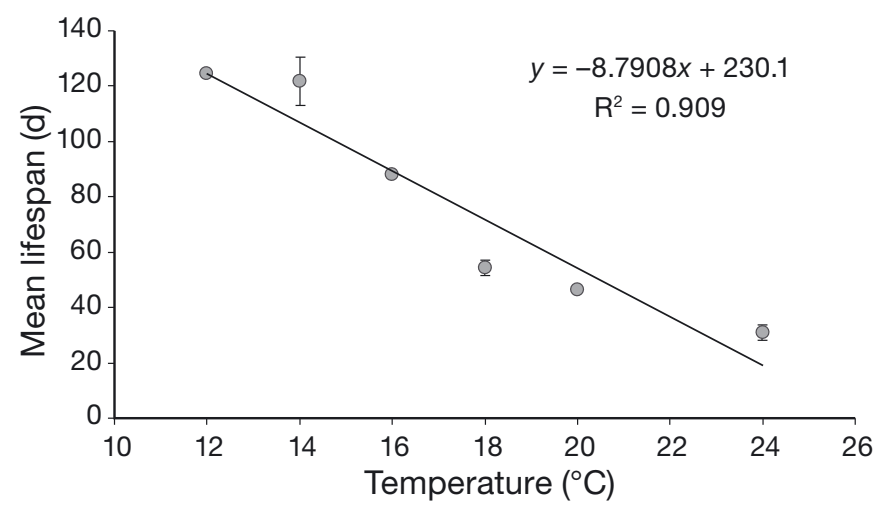

Fig. 5. Relationship between temperature and mean lifespan for female Pseudocyclops umbraticus. Circle symbols without error bars represent interpolated values from the regression line lifetime egg production was seen at $14^{\circ} \mathrm{C}\left(278.5 \pm 30.4\right.$ eggs female $\left.{ }^{-1}\right)$, with the minimum at $24^{\circ} \mathrm{C}(189.0 \pm 28.8$ eggs female ${ }^{-1}$ ). At $18^{\circ} \mathrm{C}$, lifetime egg production was $264.8 \pm 15.1$ eggs female ${ }^{-1}$.

Increasing temperatures dramatically decreased female lifespan (Fig. 5), which was $121.7 \pm 10.5 \mathrm{~d}$ at $14^{\circ} \mathrm{C}, 54.4$ $\pm 2.9 \mathrm{~d}$ at $18^{\circ} \mathrm{C}$, and $31.0 \pm 2.8$ d at $24^{\circ} \mathrm{C}$. Similarly, development times of the eggs decreased with increasing temperatures (Fig. 6a): the eggs hatched after $108 \mathrm{~h}$ at $14^{\circ} \mathrm{C}, 84 \mathrm{~h}$ at $18^{\circ} \mathrm{C}$, and $12 \mathrm{~h}$ at $24^{\circ} \mathrm{C}$. The development time from egg to adulthood also showed a similar trend, with adulthood attained in $57.3 \pm 7.0 \mathrm{~d}$ at $14^{\circ} \mathrm{C}, 40.7 \pm 6.0 \mathrm{~d}$ at $18^{\circ} \mathrm{C}$, and $19.3 \pm 3.0 \mathrm{~d}$ at $28^{\circ} \mathrm{C}$ (Fig. 6b). In contrast, the recruitment rate was lower at the low temperature $\left(9.80 \pm 1.44 \%\right.$ at $\left.14^{\circ} \mathrm{C}\right)$ than the higher temperatures $\left(17.10 \pm 5.55 \%\right.$ at $18^{\circ} \mathrm{C}, 30.25 \pm 2.33 \%$ at $\left.28^{\circ} \mathrm{C}\right)$, and was significantly related to temperature (Fig. 7).

The EPRs of $P$. umbraticus were significantly higher than those of the congeneric $P$. xiphophorus at all temperatures, as shown by 2-way ANOVA (Table 3), even though the fecundity of both of these species showed the same tolerance limits. For example, the daily mean egg production of $P$. umbraticus at $18^{\circ} \mathrm{C}$ (4.9 eggs female $\left.\mathrm{e}^{-1} \mathrm{~d}^{-1}\right)$ was higher than that estimated for $P$. xiphophorus at $20^{\circ} \mathrm{C}$. Also, P. umbraticus showed a higher correlation coefficient with temperature and a greater slope of the regression line than $P$. xiphophorus (Fig. 8).

The egg-laying behaviour in $P$. umbraticus is similar to that of $P$. xiphophorus, and is very close to being considered parental care. Within 2 to $3 \mathrm{~d}$ after achieving maturity, the females release eggs more or less continuously throughout the day, almost until the end of their life. The females do not release these eggs directly into the water; instead, after a pair of eggs is extruded from the paired gonopores, the female swims with the pair of eggs attached on either side of the genital double somite until the eggs are released by a rapid urosome stroke. After releasing the egg pair, the female swims over them with a rotatory motion, apparently secreting a substance that facilitates the adhesion of the eggs to the bottom of the Petri dish or to any hard surface, such as wood fragments, nylon filaments, filamentous algae, or leaves. The female continues to swim over the eggs until they are attached. This adhesive substance is secreted from the female mouthparts, which become so sticky that any encountered fragments can become stuck. 

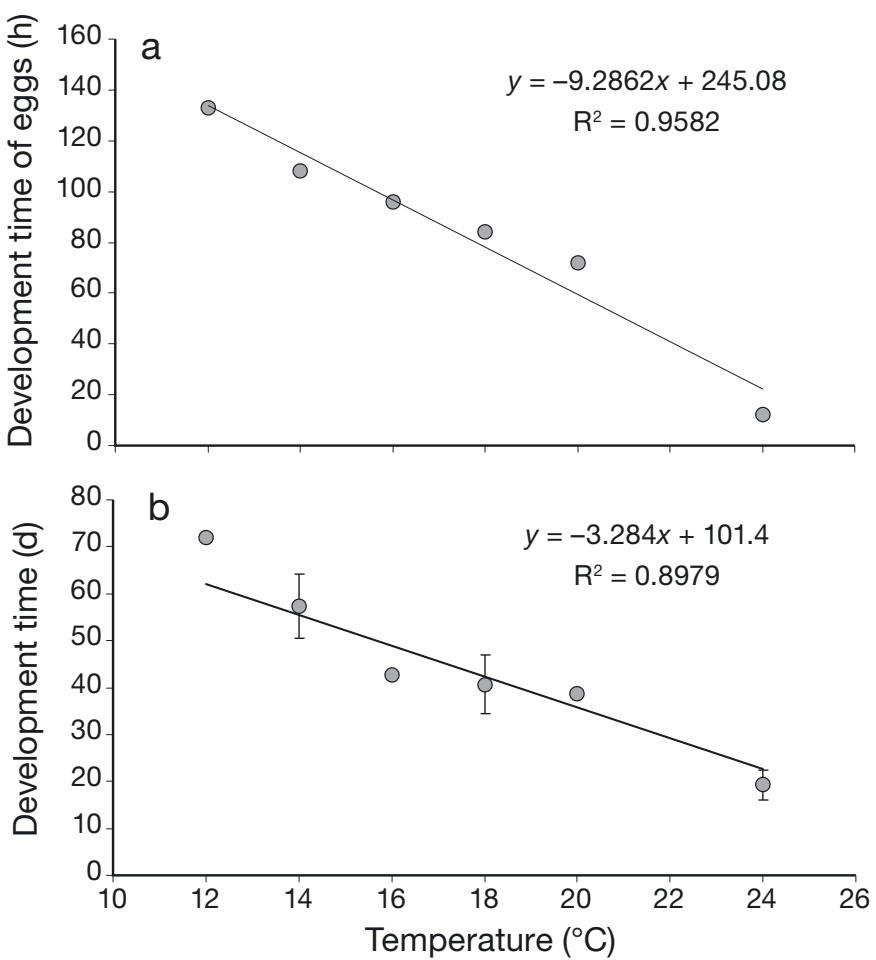

Fig. 6. Relationships between temperature and (a) mean development time of Pseudocyclops umbraticus eggs; and (b) development time from naupliar stage to adulthood. Circle symbols without error bars in (b) represent interpolated values from the regression line

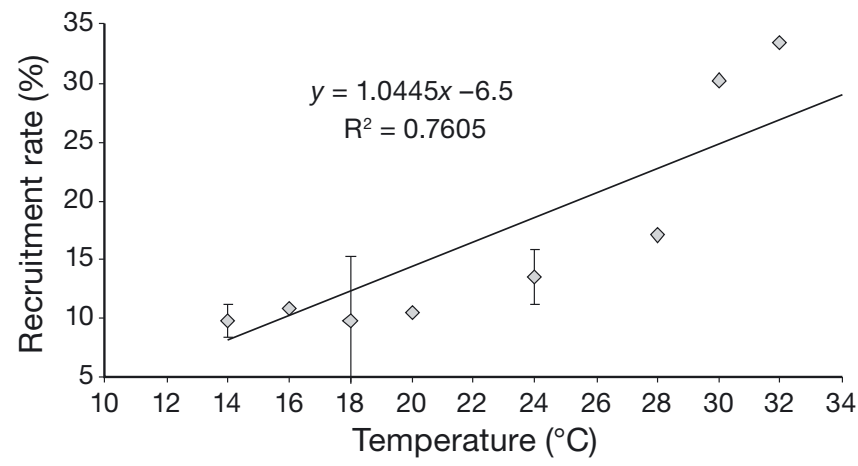

Fig. 7. Relationship between temperature and recruitment rate for female Pseudocyclops umbraticus. Symbols without error bars represent interpolated values from the regression line

Table 3. Two-way ANOVA to test the differences in mean daily egg production between Pseudocyclops umbraticus and P. xiphophorus for each temperature. Significant values are highlighted in bold

\begin{tabular}{|lccccc|}
\hline & $\begin{array}{c}\text { Sum of } \\
\text { squares }\end{array}$ & df & $\begin{array}{c}\text { Mean } \\
\text { square }\end{array}$ & $F$ & $\mathrm{p}$ \\
\hline $\begin{array}{l}\text { P. umbraticus vs. } \\
\begin{array}{l}\text { P. xiphophorus } \\
\text { Between temp. }\end{array}\end{array}$ & 1128.46 & 2 & 564.228 & 105.555 & $\mathbf{2 . 0} \times \mathbf{1 0}^{\mathbf{- 7}}$ \\
$\begin{array}{l}\text { Error } \\
\text { Total }\end{array}$ & 53.4537 & 10 & 5.34537 & & \\
\hline
\end{tabular}

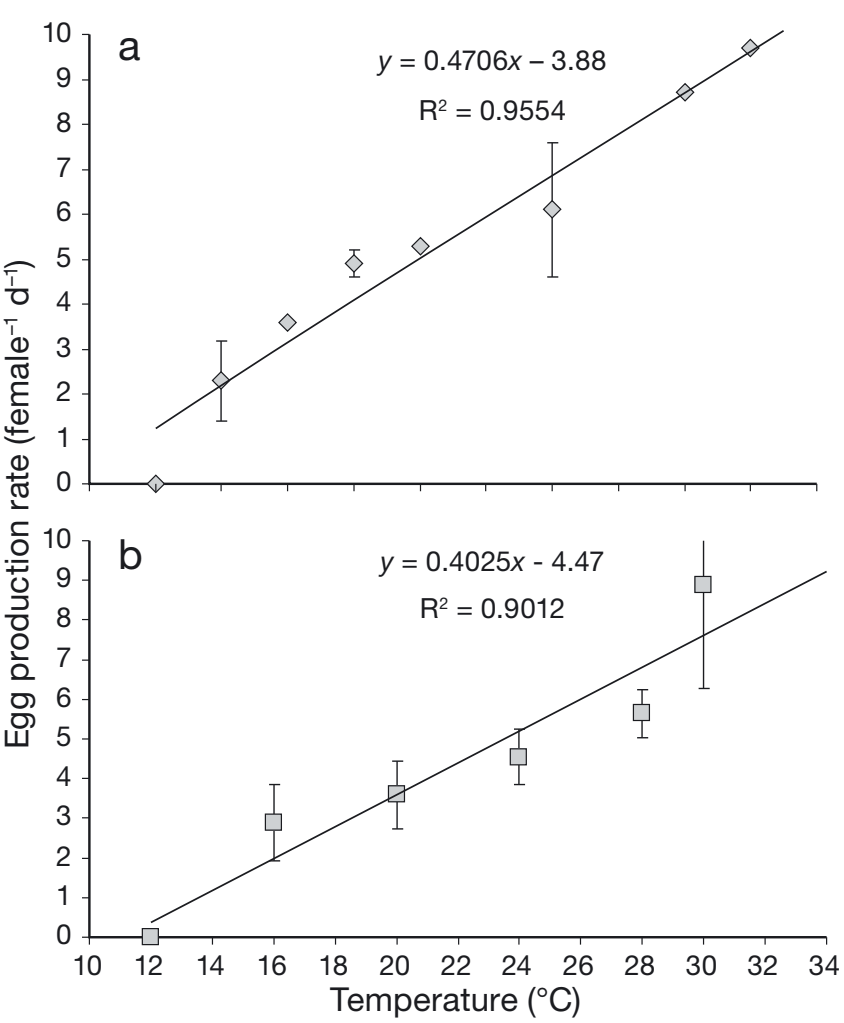

Fig. 8. Relationships between temperature and mean egg production rates in (a) Pseudocyclops umbraticus and (b) P. xiphophorus. Symbols without error bars represent interpolated values from the regression line

\section{DISCUSSION}

Following the work of Brugnano et al. $(2006,2009)$ who focused on Pseudocyclops xiphophorus, the present study represents an additional contribution to our understanding of EPR and life-history parameters of the bentho-pelagic calanoid $P$. umbraticus reared in the laboratory. We also describe its abundance trends along 5 transects in Lake Faro, where it showed high seasonal variability.

In contrast to the congeneric species $P$. xiphophorus, the maximum abundance of $P$. umbraticus occurred in the summer, although relatively high abundance was also recorded both in autumn and winter, similar to that of $P$. xiphophorus. P. umbraticus demonstrated high fecundity during the summer, with a slight decline in winter when the temperatures approached the species' lower tolerance limits. Thus, there is concurrence between adult female abundance and daily EPRs in the summer, similar to Japanese populations of Acartia clausi (Uye 1982). This concurrence was only seen for $P$. xiphophorus in November (Brugnano 
et al. 2009), when high fecundity coincided with high population density of the females.

Since development time is longer at lower temperatures, $P$. umbraticus appears to overwinter as adults or advanced copepodites, as has also been demonstrated for $P$. xiphophorus. This life strategy would allow both of these populations to survive without any pause in egg production, at least under our different experimental and temperature conditions. Smith \& Lane (1985) demonstrated how Centropages typicus spends the cooler season as CV, and this temporal pattern is similar to that reported for Rhincalanus nasutus, Pseudocalanus sp., and Paracalanus parvus (Landry 1983). During the winter, when the temperature decreases but remains above $16^{\circ} \mathrm{C}$, the abundance of $P$. umbraticus remains relatively high, although EPR declines, and the spawning, laying and development times increase. This mechanism allows the population to sustain a relatively high abundance into January. As temperatures continue to decrease, egg production declines and ultimately stops at $12^{\circ} \mathrm{C}$, which results in low abundance of $P$. umbraticus copepodites and adults in the spring. This is corroborated by the low recruitment rates estimated at lower temperatures in our laboratory experiments, which demonstrate that maximum daily EPRs occur when environmental temperatures range from 18 to $24^{\circ} \mathrm{C}$. In the spring, as the temperature increases, the $P$. umbraticus population begins to increase in numbers again.

Zagami \& Brugnano (2013) reported the total absence of all benthoplanktonic copepod species except $P$. xiphophorus in late summer throughout Lake Faro. They concluded that this absence was caused by benthic anoxia, which was enhanced by the decomposition of benthic macroalgae in the shallow waters along the shores of the lake. In contrast to P. umbraticus, P. xiphophorus lives in the fouling material associated with ropes and mooring posts in surface water, and is widespread all around Lake Faro in summer (Zagami \& Brugnano 2013). In the unfavourable conditions of high temperatures and low oxygen concentrations in the late summer-early autumn, the necessity of resting egg production for $P$. umbraticus could be hypothesized, but this needs further investigation.

The differences in seasonal and spatial abundance patterns between these congeneric species might be due to differences in physiology and/or in predation pressure. The different sensitivity of $P$. umbraticus and $P$. xiphophorus to temperature variation might be a further adaptation to their different substrate types (i.e. the bottom of shallow shorelines, and foul- ing material suspended in the water column, respectively). Indeed, P. umbraticus is more fecund at all temperatures, but less reactive than $P$. xiphophorus to a temperature increment of as little as $6^{\circ} \mathrm{C}$ (Brugnano et al. 2009). This was demonstrated in this study by the similar (not significantly different) egg production at 18 and $24^{\circ} \mathrm{C}$ by $P$. umbraticus. It appears well adapted to the high variability within shallow shore waters, which are more likely to undergo rapid changes in environmental parameters, even though it was not possible to demonstrate any significant negative effect of salinity on $P$. umbraticus abundance.

As demonstrated by Uye (1981) for Acartia omorii, although the average number of eggs produced by $P$. umbraticus is higher at higher temperatures, the period of egg laying is reduced (as in $P$. xiphophorus; Brugnano et al. 2009), and consequently, lifetime egg production is lower. The average number of eggs produced is higher at higher temperatures because of the acceleration in their metabolic activity and the associated accumulation of material in the developing oocytes, so that egg production is higher and spawning intervals are shortened (Uye 1981). In the laboratory, $P$. umbraticus egg production showed a lower temperature limit below which eggs were not produced $\left(12^{\circ} \mathrm{C}\right)$, and an optimal temperature range at which the daily EPR reached its maximum (18 to $28^{\circ} \mathrm{C}$ ). This optimum temperature range appears to be higher than that reported for most common subtemperate copepod species, which ranges from ca. $15^{\circ} \mathrm{C}$ for C. typicus, Temora stylifera and T. longicornis (Abou Debs \& Nival 1983, Van Rijswijk et al. 1989), to $20^{\circ} \mathrm{C}$ for Acartia tonsa and Sinocalanus tenellus (Kimoto et al. 1986).

$P$. umbraticus and P. xiphophorus have lower daily EPRs than most planktonic calanoid copepods in subtemperate regions (Ianora 1998). Despite these low EPRs, P. umbraticus and P. xiphophorus can survive in restricted habitats where interspecific competition, mainly with harpacticoid copepods, is high. The distinctive spawning behaviour whereby females secrete a substance (probably from the mouth apparatus) that aids in the adhesion of their eggs to the substrate appears to be characteristic of these species, and differentiates the genus from the freespawning and egg-carrying calanoids. This egglaying behaviour might represent an adaptation to a benthic habitat, to guarantee higher survival rates of the egg stages compared to other planktonic freespawning and egg-carrying calanoid species (Kiørboe \& Sabatini 1994), thereby compensating for its low population abundance and reproduction rates. 
By carrying the eggs, the female would be more susceptible to visually hunting predators (Webb \& Weaver 1988). What makes the egg-laying behaviour in these species unique is that the female continues to swim over the eggs and contributes to their attachment to the substrate, an action that corresponds to the movement of their mouthparts. To our knowledge, this egg-laying behaviour has never been observed before for copepods.

As the biology and ecology of this particular group of bentho-pelagic calanoid species is poorly known, further studies are currently underway. These include determination of the trophic requirements of $P$. umbraticus, which are of particular interest due to their migratory habits, where $P$. umbraticus move upwards from the daytime bottom-water interface habitat, into the water column at night (Damkaer 1970, Alldredge \& King 1985, Ohtsuka 1985, Jacoby \& Greenwood 1988, Campolmi et al. 2002), as demonstrated by the diversity increase in the lake during the night (Zagami \& Brugnano 2013). Thus, $P$. umbraticus can feed on both planktonic and benthic communities. Brugnano et al. (2009) observed higher in situ egg production for $P$. xiphophorus than in laboratory experiments, which they attributed to a deficiency in the diet fed to the copepods in the laboratory.

We were unable to study the in situ feeding behaviour of Pseudocyclops species because of their rarity, but additional efforts will be made in future studies. However, there is evidence in the literature that mixed diets increase fecundity, and that the combination of a dinoflagellate and ciliate diet contributes more than a monospecific diet. A mixed diet can improve egg production by allowing any lack of nutrients in one food source to be supplemented by another food source (Kleppel et al. 1991). Studies on the effects of different food items on the egg production and hatching success of $P$. xiphophorus have already demonstrated different responses to a phytoplankton diet (Brugnano et al. 2008).

When compared to other more abundant pelagic copepods, $P$. umbraticus is much less fecund, even though the maximum daily EPRs (from 6 to 8 eggs female $\mathrm{e}^{-1} \mathrm{~d}^{-1}$ at 28 and $30^{\circ} \mathrm{C}$ ) are within the range of values reported for egg-carrying species (Mauchline 1998, Lee et al. 2003). The high hatching success and unique egg-laying behaviour of this bentho-pelagic genus may also contribute to higher survival rates of egg stages compared to free-spawning species (Kiørboe \& Sabatini 1994). The greater fecundity at higher temperatures compared to other subtemperate species, which generally show maximum EPRs at 15 to $20^{\circ} \mathrm{C}$ (Ianora 1998), indicates that P. umbraticus is well adapted to the higher temperatures of coastal and brackish water environments, where it contributes to the biofouling community. However, EPRs of $P$. umbraticus are similar to those reported for some key pelagic calanoid species that are typical of these transitional environments, such as Paracartia latisetosa (from $0.5 \pm 1.1$ eggs female ${ }^{-1} \mathrm{~d}^{-1}$ in May, to 6.5 \pm 2.1 eggs female ${ }^{-1} \mathrm{~d}^{-1}$ in August; Belmonte \& Pati 2007). In any case, they are evenly low when compared to values obtained when rearing the same species on a Prorocentrum minimum diet $(20.0 \pm$ 12.2 eggs female ${ }^{-1} \mathrm{~d}^{-1}$ at $18^{\circ} \mathrm{C}$ ) under food satiation conditions (C. Brugnano et al. unpubl. data). The reliability of these data is supported by comparing the mean abundances of $P$. latisetosa and $P$. umbraticus in Lake Faro: 195.5 ind. $\mathrm{m}^{-3}$, and 0.32 ind. $\mathrm{m}^{-3}$, respectively (Zagami \& Brugnano 2013).

\section{CONCLUSIONS}

We have shown here that, although Pseudocyclops umbraticus and $P$. xiphophorus compared are in the same genus, they show significant differences in some important life-history traits, and different physiological adaptations to temperature in relation to substrate type. These bentho-pelagic calanoids can be defined as eurythermic, with a wide range of temperature tolerance, such that they are well adapted to live in the shallow coastal and transitional environments where their low EPRs are balanced by the high naupliar survival rates, which in turn may reflect their unique egg-laying behaviour.

Acknowledgements. We thank Dr. Christopher Berrie for his English revision and suggested improvements of our manuscript. We are grateful to all anonymous reviewers for their useful suggestions which improved our manuscript.

\section{LITERATURE CITED}

Abou Debs C, Nival P (1983) Étude de la ponte et du dévelopement embryonnaire in relation avec la température et la nourriture chez Temora stylifera Dana (Copepoda: Calanoida). J Exp Mar Biol Ecol 72:125-145

Alldredge AL, King JM (1985) The distance demersal zooplankton migrate above the benthos: implication for predation. Mar Biol 84:253-260

Ban S (1994) Effect of temperature and food concentration on postembryonic development, egg production and adult body size of calanoid copepod Eurytemora affinis. J Plankton Res 16:721-735

Belmonte G, Pati AC (2007) Hatching rate and diapause duration in eggs of Paracartia latisetosa (Copepoda: Calanoida). J Plankton Res 29(Suppl):i39-i47 
Brugnano C, Zagami G, Granata A (2006) Preliminary data on egg production rates of Pseudocyclops xiphophorus Wells, 1967 from the brackish Lake Faro (north-eastern Sicily). Chem Ecol 22(Suppl 1):S191-S195

- Brugnano C, Guglielmo L, Zagami G (2008) Food type effects on reproduction of hyperbenthic calanoid species Pseudocyclops xiphophorus Wells, 1967, under laboratory conditions. Chem Ecol 24:111-118

Brugnano C, Guglielmo L, Ianora A, Zagami G (2009) Temperature effects on fecundity, development and survival of the benthopelagic calanoid copepod, Pseudocyclops xiphophorus. Mar Biol 156:331-340

Campolmi M, Zagami G, Pellerito R, Granata A, Mazzola A (2002) Spatio-temporal variations in a population of hyperbentonic calanoids (Crustacea: Copepoda) in a Mediterranean coastal environment. Biol Mar Medit 9: 350-357 (in Italian with English abstract)

Corkett CJ, McLaren IA (1978) The biology of Pseudocalanus. Adv Mar Biol 15:1-231

Damkaer DM (1970) Parastephos occatum, a new species of hyperbenthic copepod (Calanoida: Stephidae) from inland marine waters of Washington state. Proc Biol Soc Wash 83:505-514

Genovese S (1963) Osservazioni preliminari sullo zooplancton degli stagni salmastri di Ganzirri e di Faro. Boll Pesca Piscic Idrobiol 1:1-12

Hammer Ø, Harper DAT, Ryan PD (2001) PAST: paleontological statistics software package for education and data analysis. Palaeontol Electronica 4:1-9. http://palaeoelectronica.org/2001_1/past/issue1_01.htm

Huys R, Boxshall GA (1991) Copepod evolution. The Ray Society, London

Ianora A (1998) Copepod life history traits in subtemperate regions. J Mar Syst 15:337-349

Jacoby CA, Greenwood JG (1988) Spatial, temporal and behavioural patterns in emergence of zooplankton in the lagoon of Heron Reef, Great Barrier Reef, Australia. Mar Biol 97:309-328

Kimoto K, Uye SI, Onbè T (1986) Egg production of a brackish-water calanoid copepod Sinocalanus tenellus in relation to food abundance and temperature. Bull Plankton Soc Japan 33:133-145

Kiørboe T, Sabatini M (1994) Reproductive and life cycle strategies in egg-carrying cyclopoid and free spawning calanoid copepods. J Plankton Res 16:1353-1366

Kiørboe T, Møhlenberg F, Hamburger K (1985) Bioenergetics of the planktonic copepod Acartia tonsa: relation between feeding, egg production and respiration, and composition of specific dynamic action. Mar Ecol Prog Ser 26:85-97

Kleppel GS, Holliday DV, Pieper KE (1991) Trophic interac-

Editorial responsibility: Ferdinando Boero,

Lecce, Italy tions between copepods and microplankton: a question about the role of diatoms. Limnol Oceanogr 36:172-178

Landry MR (1983) The development of marine calanoid copepods with comment on the isochronal rule. Limnol Oceanogr 28:614-624

Lee HW, Ban S, Ikeda T, Matsuishi T (2003) Effect of temperature on development, growth and reproduction in the marine copepod Pseudocalanus newmani at satiating food condition. J Plankton Res 25:261-271

Mauchline J (1998) The biology of calanoid copepods. Academic Press, London

Ohtsuka S (1985) Calanoid copepods collected from the near-bottom in Tanabe Bay on the Pacific coast of the Middle Honshu, Japan. II. Arietellidae (cont.). Publ Seto Mar Biol Lab 30:287-306

Runge JA (1988) Should we expect a relationship between primary production and fisheries? The role of copepod dynamics as a filter of trophic variability. Hydrobiologia 167-168:61-71

Smith SL, Lane PVZ (1985) Laboratory studies of the marine copepod Centropages typicus: egg production and development rates. Mar Biol 85:153-162

$>$ Sorokin YI, Donato N (1975) On the carbon and sulphur metabolism in the meromictic Lake Faro (Sicily). Hydrobiologia 47:241-252

Trüpper HG, Genovese S (1968) Characterization of photosynthetic sulfur bacteria causing red water in Lake Faro (Messina, Sicily). Limnol Oceanogr 13:225-232

Uye SI (1981) Fecundity studies of neritic calanoid copepods Acartia clausi Giesbrecht and A. steueri Smirnov: a simple empirical model of daily egg production. J Exp Mar Biol Ecol 50:255-271

- Uye SI (1982) Population dynamics and production of Acartia clausi Giesbrecht (Copepoda: Calanoida) in inlet waters. J Exp Mar Biol Ecol 57:55-83

Van Rijswijk P, Bakker C, Vink M (1989) Daily fecundity of Temora longicornis (Copepoda: Calanoida) in the Oosterschelde Estuary (SW Netherlands). Neth J Sea Res 23: 293-303

- Webb DG, Weaver AJ (1988) Predation and the evolution of free spawning in marine calanoid copepods. Oikos 51: 189-192

> Zagami G, Brugnano C (2013) Diel, seasonal and maninduced changes in copepod assemblages and diversity, with special emphasis on hyperbenthic calanoid species, in a Mediterranean meromictic system (Lake Faro). Mar Freshw Res 64:951-964

Zagami G, Costanzo G, Crescenti N (2005) First record in Mediterranean Sea and redescription of the benthoplanktonic calanoid copepod species Pseudocyclops xiphophorus Wells, 1967. J Mar Syst 55:67-76

Submitted: December 27, 2013; Accepted: February 27, 2014 Proofs received from author(s): April 23, 2014 